Sains Malaysiana 50(1)(2021): 73-83

http://dx.doi.org/10.17576/jsm-2021-5001-08

\title{
Harvesting Marine Microalgae Nannochloropsis sp. using Dissolved Air Flotation (DAF) Technique
}

(Penuaian Mikroalga Marin Nannochloropsis sp. menggunakan Teknik Pengapungan Udara Terlarut (DAF))

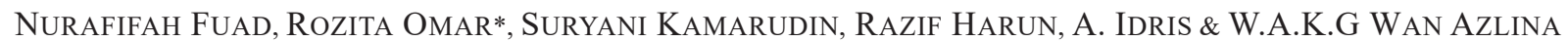

\begin{abstract}
The production of high-value bioproducts from microalgae biomass has been widely investigated. However, their production is hindered by the expensive harvesting process. To date, flocculation followed by DAF process has been accepted as one of the affordable harvesting approaches. In this study, the use of DAF technique was attempted to harvest marine microalgae Nannochloropsis sp. Batch DAF harvesting was carried out using fabricated DAF unit equipped with several compartments including separation column, product collecting vessel and rotary skimmer. Tannin-based biopolymer flocculant, AFlok-BP1 at pH 5 with a concentration of $160 \mathrm{mg} / \mathrm{L}$ was used to facilitate the flocculation of particles. The effects of different saturator pressure at 1.8, 2, and 2.2 bar were then evaluated at a constant volume of $6 \mathrm{~L}$ microalgae culture. The effects of different microalgae culture volumes (6, 8 and $10 \mathrm{~L})$ were also evaluated at a fixed saturator pressure of 2.2 bar. The highest pressure at 2.2 bar yielded the best result with the highest total solid of $3.19 \pm 0.01 \%$ and a maximum yield of $1.70 \pm 0.05 \mathrm{~g} / \mathrm{g}$ (wet basis). The microalgae concentration was the lowest $(0.027 \mathrm{~g} / \mathrm{L})$ when $6 \mathrm{~L}$ of culture volume was used. However, the values were significantly higher when the culture volume was increased to 8 and $10 \mathrm{~L}$ to approximately 0.035 and $0.050 \mathrm{~g} / \mathrm{L}$, respectively. As a conclusion, the study provided evidence for the feasibility of DAF technique in harvesting marine microalgae Nannochloropsis sp.
\end{abstract}

Keywords: Bubbles; dewatering; flotation; microalgae; saturator

ABSTRAK

Penghasilan produk biologi yang bernilai tinggi daripada biojisim mikroalga telah dikaji dengan meluas. Namun begitu, penghasilan produk biologi ini terhalang oleh proses penuaian yang mahal. Sehingga hari ini, kaedah flokulasi diikuti dengan proses pengapungan udara terlarut (DAF) telah diterima baik sebagai satu kaedah penuaian yang berpatutan. Dalam kajian ini, kaedah DAF telah diguna pakai untuk menuai mikroalga marin Nannochloropsis sp. Penuaian DAF secara kelompok telah dijalankan menggunakan unit DAF yang telah difabrikasi dan dilengkapkan dengan beberapa bahagian termasuklah turus pemisah, vesel pengumpulan produk dan pemeres putar. Flokulan biopolimer berasaskan tanin, AFlok-BP1 telah digunakan pada nilai pH 5 dengan kepekatan 160 mg/L untuk memudahkan proses flokulasi zarah-zarah. Kesan tekanan penyerapan yang berbeza pada 1.8, 2.0 dan 2.2 bar kemudiannya dinilai pada isi padu tetap kultur mikroalga iaitu 6 L. Kesan isi padu mikroalga kultur yang berbeza (6, 8 dan 10 L) juga dinilai menggunakan tekanan penyerapan yang tetap iaitu 2.2 bar. Tekanan paling tinggi pada 2.2 bar memberikan keputusan terbaik dengan jumlah pepejal tertinggi, $3.19 \pm 0.01 \%$ dan hasil maksimum, $1.70 \pm 0.05$ $\mathrm{g} / \mathrm{g}$ (asas basah). Kepekatan mikroalga adalah paling rendah $(0.027 \mathrm{~g} / \mathrm{L})$ apabila isi padu kultur $6 \mathrm{~L}$ digunakan. Walau bagaimanapun, nilai tersebut meningkat secara signifikan dengan penambahan isi padu kultur dari 8 dan 10 L dengan anggaran sebanyak 0.035 dan $0.050 \mathrm{~g} / \mathrm{L}$. Kesimpulannya, kajian ini telah membuktikan keupayaan teknik DAF untuk menuai mikroalga marin Nannochloropsis sp.

Kata kunci: Buih; mikroalga; penyahairan; pengapungan; penyerapan

\section{INTRODUCTION}

Lately, microalgae biomass harvest for various applications such as biofuel and production of bioproducts is receiving lots of attention. This is due to the high amount of valuable components including lipids, proteins, and carbohydrates within the microalgae biomass. These components can be converted to various profitable products such as nutraceuticals, cosmetics, aquaculture feed, and fine organic chemicals (Gerardo et al. 2015; Harun et al. 2010). 
Magnetic separation has recently been developed as an interesting alternative, but it is energy intensive due to the use of additional equipment such as compressors and shear mills to separate magnetic nanoparticles from microalgal flocs (Gerardo et al. 2015). Meanwhile, the suitability of the filtration method depends solely on the size of microalgal particles, as larger particles are preferable for easy filtration (Harun et al. 2010). Next, flocculation is known to be an economically feasible method. This process could potentially increase the particle sizes of the microalgal particles and is often performed as a pretreatment for another method (Sharma et al. 2013). Hence, the selection of flocculants is crucial for this technique especially when it is followed by the flotation technique. This can be achieved by adding various types of flocculants such as cationic polymers such as chitosan, cationic starch, and tannin-based flocculants, metal salts such as aluminium sulphate, ferric chloride and ferric sulphate, and alkaline induced $\mathrm{pH}$ by addition of base and biological flocculants such as bacteria, fungi, and algae (Besson \& Guirard 2013; Fuad et al. 2018; Gerardo et al. 2015; Kim \& Kwak 2020; Zhang et al. 2016). However, in food or feed applications, flocculation by metal salts is undesirable due to toxic chemicals used during the harvest (Gerardo et al. 2015).

Flotation is the separation method based on the generation of air or gas bubbles that adhere onto the destabilised microalgal flocs. Flotation process can be classified into different types based on the bubble generation method such as DAF, dispersed air flotation (DiAF) and electrolytic flotation (Barros et al. 2015; Ndikubwana et al. 2016; Sharma et al. 2013; Wiley et al. 2009). Among the three different flotation approaches, DAF which can be subjected to large-scale application is being widely used for drinking water clarification and separation of microalgae from wastewater (Edzwald 2010; Gerardo et al. 2015; Han et al. 2007; Sharma et al. 2013). However, the efficiency of DAF relies on several factors such as saturator pressure, recycle ratio, bubble or particle size, surface charge as well as initial algal concentrations (Kim et al. 2017; Zhang et al. 2014). Since flocculation is often applied as a pre-treatment method prior to DAF as mentioned earlier, suitable flocculant has to be selected to ensure effective flotation performance in order to enhance collision or adhesion between the bubbles and particles (Barros et al. 2015). Furthermore, several recent studies have reported on the positively charged bubble surface modification technique which is referred to as 'PosiDAF' to be effective in microalgae harvesting (Kim et al. 2017; Laamanen et al. 2016). This method eliminates the coagulation stage compared to the conventional DAF method where the chemicals are directly added into the saturator (Laamanen et al. 2016). Nevertheless, more study is needed to evaluate the applicability of this technique for large-scale production.
Previously, Besson and Guiraud (2013) carried out a $\mathrm{pH}$-induced flocculation followed by flotation with the addition of sodium hydroxide in harvesting hypersaline microalga Dunaliella salina. This method proved that microalgae were able to form flocs spontaneously at higher $\mathrm{pH}$ and simulate auto-flocculation (Barros et al. 2015; Gerardo et al. 2015; Kim \& Kwak 2020; Leite et al. 2019). Microalgal biomass harvest using magnesium coagulation with dissolved air flotation has also been reported in harvesting freshwater microalgae such as Chlorella zofingiensis and Scenedesmus dimorphus, and marine microalgae such as Nannochloropsis sp. Moreover, lab scale DAF study only been investigated by Kwon et al. (2014) to harvest marine microalgae, Tetraselmis sp. KCTC12236BP at $2 \mathrm{~atm}$ (2.03 bar). Hence, limited studies have been reported on the harvesting of microalgal biomass especially for marine species. Since marine microalgae are currently receiving significant attention due to their high quantities of valuable compounds (Barros et al. 2015), the marine microalga Nannochloropsis sp. was selected for this study as it was worth exploring compared to freshwater microalgae (Liu et al. 2017). This study assessed the flocculation method using tannin-based biopolymer AFlok-BP1 followed by batch dissolved air flotation separation method. Furthermore, the effectiveness of DAF in terms of different saturator pressure and volume of microalgal culture added to the unit were also investigated.

\section{MATERIALS AND METHODS}

\section{CULTIVATION OF Nannochloropsis sp.}

The marine microalga, Nannochloropsis sp. strain, was supplied by CSIRO Microalgae Research Centre, Australia. The species was cultivated at the Green Laboratory, Faculty of Engineering UPM Serdang by employing the modified $\mathrm{F}^{* *}$ medium which has been reported in a previous study (Fuad et al. 2018). The composition of the modified medium contained $\mathrm{KNO}_{3}$ $(1155 \mathrm{mg} / \mathrm{L}), \mathrm{NaH}_{2} \mathrm{PO}_{4} \cdot \mathrm{H}_{2} \mathrm{O}(103 \mathrm{mg} / \mathrm{L}), \mathrm{MnCl}_{2} \cdot 4 \mathrm{H}_{2} \mathrm{O}$ $(2.4 \mathrm{mg} / \mathrm{L}), \mathrm{ZnSO}_{4} .7 \mathrm{H}_{2} \mathrm{O}(4.5 \mathrm{mg} / \mathrm{L}), \mathrm{Co}\left(\mathrm{NO}_{3}\right)_{2} \cdot 6 \mathrm{H}_{2} \mathrm{O}(0.1$ $\mathrm{mg} / \mathrm{L}), \mathrm{CuSO}_{4} \cdot 5 \mathrm{H}_{2} \mathrm{O}(0.71 \mathrm{mg} / \mathrm{L}), \mathrm{Na}_{2} \mathrm{MoO}_{4} \cdot 2 \mathrm{H}_{2} \mathrm{O}(0.1 \mathrm{mg} /$ $\mathrm{LNa}_{2} \mathrm{SiO}_{3}(22.7 \mathrm{mg} / \mathrm{L})$, and $\mathrm{FeC}_{6} \mathrm{H}_{5} \mathrm{O}_{7}(3 \mathrm{mg} / \mathrm{L})$. Salinity of $35 \mathrm{~g} / \mathrm{L}$ was achieved by the addition of artificial salts to replace seawater. The culture was prepared in batches using 10 L laboratory Schott bottles under a continuous fluorescent light in an air-conditioned room maintained at $25{ }^{\circ} \mathrm{C}$. Microalgal culture was harvested during the exponential phase which took about 14 days with a biomass concentration at $1 \mathrm{~g} / \mathrm{L}$.

\section{DISSOLVED AIR FLOTATION UNIT}

In this study, the DAF was designed and fabricated by Lab Solutions, ILIR Niaga Sdn Bhd located in Selangor, 
Malaysia. Figure 1 shows the detailed schematic drawing of the fabricated DAF unit. The unit was divided into several compartments. The first compartment $(150 \times 200$ $\times 540 \mathrm{~mm}$ ) comprised several baffles for the purpose of mixing the samples with the flocculant. The second compartment $(300 \times 200 \times 540 \mathrm{~mm})$ was known as the flotation column which acted as a contact zone for the bubbles and microalgal particles. Bubbles generated at this zone attached themselves to the microalgal particles to bring them to the surface. Another compartment which was specified as the separation zone then allowed the separation of the floated microalgal biomass and clean water. The collecting vessel which was provided could hold up to $5 \mathrm{~L}$ volumes of samples. Air supply came from an aquarium air pump (JIY-328, JIX ${ }^{\circledR}$, China) which was channelled using air tube and connected to the valve (Specifications; Output: $2 \times 4.5 \mathrm{~L} / \mathrm{min}$; Pressure: $2 \times 0.015 \mathrm{Mpa}$; power: $4 \mathrm{~W}$ ). Water pump (20QY-1DS, Specifications: Power: $0.55 \mathrm{~kW}$; Q: $1 \mathrm{~m} / \mathrm{h}$; n: $2900 \mathrm{r} / \mathrm{min}$; $\mathrm{H}: 40 \mathrm{~m}$ ) was used to pump the water into the saturator and throughout the entire process. The saturator $(50 \mathrm{~mm}$ $\varnothing)$ which was made from stainless steel (SUS 304) was used to saturate the water with air. In addition, this DAF unit could bear up to 3 bar. The rotary skimmer system for this DAF unit was a chain drive system with variable speed (Oriental motor, model BMUD200-C) ranging from 50 to $4000 \mathrm{rpm}$. The direction of the skimmer could be adjusted in two directions (forward or reverse).

\section{DISSOLVED AIR FLOTATION UNIT OPERATION PROCEDURES}

During the start-up, all valves were kept closed. Tap water was filled to the desired level in all the compartments. The gate valve (V-1) was fully opened to ensure the flow of the clean water into the water pump. When V-1 was opened, the discharging water valves (V-6 and V-7) were fully closed. The water pump was then switched on. An air pump was used to supply air for the flow through the system with adjustments done using the needle valve (V-2). Following air dissolution in water for about $1 \mathrm{~min}$, the air saturated water valve $(\mathrm{V}-5)$ was opened. The air supply valve and air saturated valves were adjusted until the desired saturator pressures (1.8, 2.0 and 2.2 bar) were achieved. The highest pressure could only be achieved at 2.2 bar and it was chosen as the reference for other selections of pressure. Once the saturator pressure was fixed and the bubble generation was stable, the flocculated microalgal samples were added for flotation experiments. Upon the completion of the flotation experiment at fixed flotation time (30 $\mathrm{min})$, the rotary skimmer was switched on to harvest the microalgal biomass into the collecting vessel through a valve (V-8). After all the biomass was collected, the last step of terminating a cycle was to power off the air supply, water pump and rotary skimmer. All the valves including V-1, V-2, V-3, V-4 and V-5 were closed whereas discharging water valve (V-6 and V-7) were fully opened to discharge the used water for cleaning purpose. Figure 2 shows the fabricated DAF unit used for this study.

\section{FLOCCULATION EXPERIMENTS}

Tannin-based biopolymer flocculant, AFlok-BP1, was purchased from Pakar Go Green Sdn. Bhd. Malaysia. This flocculant was chosen based on its effectiveness reported by Fuad et al. (2018). The test dosage of $160 \mathrm{mg} / \mathrm{L}$ of AFlok-BP1 at an optimized $\mathrm{pH}$ of 5 was used based on previous work (Fuad et al. 2018). A fresh AFlok-BP1 stock solution was prepared at $10 \%(\mathrm{w} / \mathrm{v})$. Flocculation experiment was carried out inside the 10-12 L basin. Microalgal samples were poured into the basin. The $\mathrm{pH}$ of the samples was adjusted to $\mathrm{pH} 5$ using $\mathrm{pH}$ meter. The samples were then dosed with $160 \mathrm{mg} / \mathrm{L}$ of AFlok-BP1 and was manually stirred for 2 to $3 \mathrm{~min}$. The samples were then immediately poured into the flotation column as the DAF was ready.

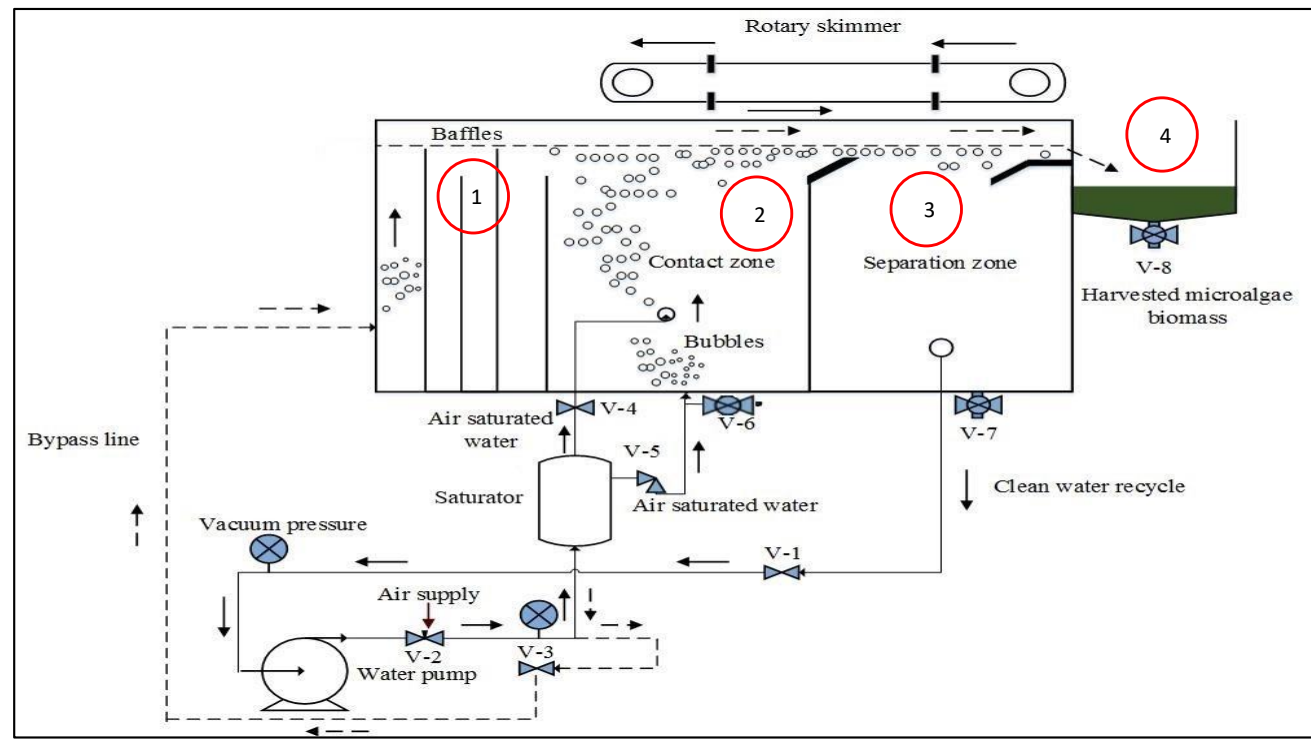

FIGURE 1. The schematic drawing of dissolved air flotation unit (Compartment labelled 1: Baffle unit, 2: Flotation unit, 3: Separation unit, 4: Biomass collecting vessel) 


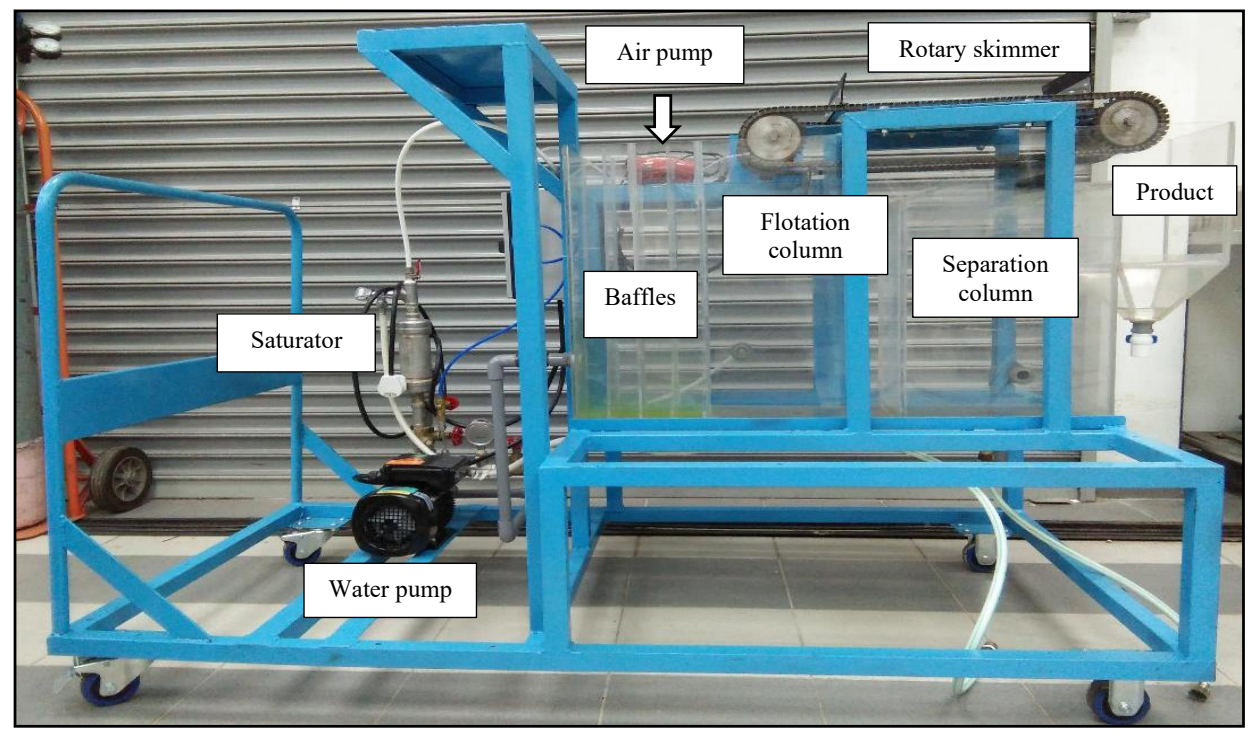

FIGURE 2. Fabricated DAF unit

\section{BATCH DISSOLVED AIR FLOTATION EXPERIMENT}

In this experiment, the dissolved method was performed in a batch mode. The experiment was designed based on two effects which were the saturator pressure and the addition of different volumes of microalgal stock. The experimental design involved the evaluation of different saturator pressures at 1.8, 2, and 2.2 bar using a culture volume of $6 \mathrm{~L}$. In addition, the effect of different concentrations was also carried out using different initial volumes of samples at 6,8 , and $10 \mathrm{~L}$. For both the saturator pressure and algal concentration experimental designs, the saturator pressure was adjusted accordingly prior to the flocculation process to ensure stable bubble formation. The water level in the separation cell was reduced according to the initial volume of alga added into the flotation cell. Flocculation experiment was performed using different volumes of microalgal samples. Then, the sample was immediately poured into the flotation cell and the timer was started. The flotation experiment was carried out for 30 $\min$. An aliquot of the sample was collected from different levels (height) of the flotation column at 10, 20,30, and $40 \mathrm{~cm}$, respectively, for optical density measurement for the first $0 \mathrm{~min}$ and every $5 \mathrm{~min}$ intervals. Figure 3 displays the labelling of the flotation column height. Finally, the optical density values at wavelength of $600 \mathrm{~nm}$ were obtained using UV-VIS spectrophotometer (GENESYS 10 UV, Thermo Electron Corporation, USA) and then converted to microalgal concentration using the equation of dry weight measurement as shown in (1):

$$
x=\frac{y}{0.4652}
$$

where $\mathrm{y}$ is the optical density value and $\mathrm{x}$ is the biomass concentration $(\mathrm{g} / \mathrm{L})$. Upon reaching $30 \mathrm{~min}$, the air pump and valves were turned off or closed. The floating microalgae were then collected using a rotary skimmer at the speed of $50 \mathrm{rpm}$. The harvested samples were subjected to total solid (\%) and yield measurements. All experiments were carried out in duplicates.

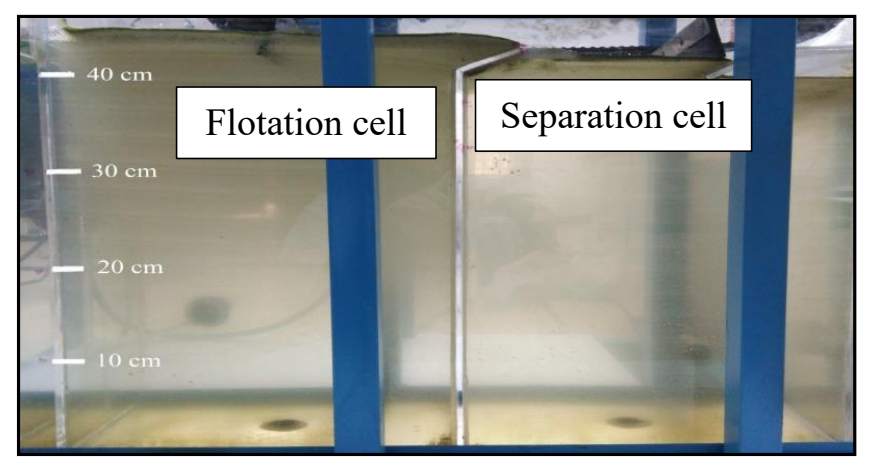

FIGURE 3. Different flotation column height 
TOTAL SOLID MEASUREMENT (\%)

The harvested microalgal biomass was subjected for total solid measurement after each run. The total solid measurement was performed according to the standard method of APHA 2540 B. A $10 \mathrm{~mL}$ of well-mixed microalga harvested was pipetted into a clean and dry crucible. Then, the sample was dried in a drying oven (Memmert Oven, USA) at $105 \pm 2{ }^{\circ} \mathrm{C}$. After $1 \mathrm{~h}$, the dried sample was taken out, let to cool in a desiccator and weighed. The cycle was repeated until a constant weight was obtained or the weight change of less than $4 \%$ was noted. The percentage of total solids was calculated based on (2):

$$
\text { Total solid }(T S)=\frac{W_{c, d}-W_{c}}{W_{c, w}-W_{c}} \times 100
$$

where $\mathrm{W}_{\mathrm{c}}$ is the weight of the crucible $(\mathrm{g}), \mathrm{W}_{\mathrm{c}, \mathrm{d}}$ is the weight of the crucible and dry sample $(\mathrm{g})$, and $\mathrm{W}_{\mathrm{c}, \mathrm{w}}$ is the weight of the crucible and wet sample $(\mathrm{g})$.

\section{YIELD OF HARVESTED BIOMASS (WET BASIS)}

The harvested microalgal biomass was collected and centrifuged to obtain the wet weight. The biomass yield was calculated as (3):

Biomass yield $=\frac{W_{f}}{W_{i}}\left(\frac{g \text { of harvested microalgae biomass }}{g \text { of initial concentration of microalgae samples }}\right)$

where $\mathrm{W}_{\mathrm{f}}$ is the weight of the sample harvested after centrifugation $(\mathrm{g})$, and $\mathrm{W}_{\mathrm{i}}$ is the initial weight of samples based on microalgae culture volume used.

\section{RESULTS AND DISCUSSION}

A tannin-based biopolymer, AFlok-BP1, was chosen for the current study based on previous experimental work on the flocculation experiment (Fuad et al. 2018). The addition of AFlok-BP1 into microalgal culture was efficient in flocculating Nannochloropsis sp. with maximum destabilisation of microalgal surface charge using $160 \mathrm{mg} / \mathrm{L}$ of dosage in an acidic condition $(\mathrm{pH} \mathrm{5)}$. Although the removal of microalgae using the dissolved air flotation method has been reported by previous studies through the control of zeta potential, successful flotation relies on the efficiency of particle-bubble attachment (Henderson et al. 2008; Kim et al. 2017). The range of zeta potential between -8 and $+2 \mathrm{mV}$ provides optimum removal efficiency with respect to the combination of coagulant dose and $\mathrm{pH}$ adjustment for flotation (Henderson et al. 2008). In this study, a much lower zeta potential values were obtained using AFlok-BP1, $-0.33 \pm 0.27 \mathrm{mV}$ (Fuad et al. 2018), which theoretically increased the particlebubble attachment. Thus, the concentration was used for DAF experiment.

\section{EFFECT OF DIFFERENT SATURATOR PRESSURE}

Saturator pressure is important for dissolved air flotation technique as it affects the bubble size or the quantity of air bubbles (Edzwald 2010; Leite et al. 2019). Highest pressure at 2.2 bar generated a concentrated cloud of milky bubble solution compared to 1.8 bar and 2 bar. Larger bubbles were observed at the lowest pressure of 1.8 bar. Referring to Henry's law, high pressure produced smaller sized bubbles (Dassey \& Theegala 2012). A previous study used an unpacked saturator unit to optimise the air dissolution parameters for DAF which also included the effect of pressure (Dassey \& Theegala 2012). Based on their results, the pressure varied from 445 to $621 \mathrm{kPa}$ (4.45 to 6.21 bar) at a fixed temperature of $21^{\circ} \mathrm{C}$. As the pressure was increased to $621 \mathrm{kPa}$, a greater solubility of air was obtained with an increase in the average bubble production.

In general, the size of the bubbles decreases as the saturator pressure increases (Gulden et al. 2020; Zhang et al. 2015). On the other hand, Han et al. (2007) studied the effects of floc and bubble sizes on the efficiency of DAF. They demonstrated that the critical floc size and bubble size decreased as the pressure was increased. Later on, Zhang et al. (2015) evaluated the effects of saturator pressure on the bubble size measurement. Based on their study, increasing the saturator pressure to $0.4 \mathrm{MPa}$ (4 bar) decreased the bubble size. However, one of the limitations in this study is the unavailability of the measurement devices to measure the bubble size.

On the contrary, bubbles can also exhibit negatively charged surface (Edzwald 2010), similar to the negatively charged surface of microalga. This phenomenon was also found in this study which was not good in terms of flotation. The microalgal surface charge of Nannochloropsis sp. culture in this study was recorded at $-27.05 \pm 0.86 \mathrm{mV}$ (Fuad et al. 2018). Meanwhile, bubbles were negatively charged in the range of -25 to $-150 \mathrm{mV}$ without the presence of flocculants (Edzwald 2010; Han et al. 2007). Generally, in order to enhance the collision efficiency between microalgal particles and bubbles, those values should be of opposite charges. Thus, low removal efficiency can be yielded when both bubbles and microalgal particles exhibit similar charges (Kim et al. 2017). The addition of AFlok-BP1 caused a significant reduction of zeta potential value which enhanced the interaction between the bubbles and flocs.

The microalgal concentration at different flotation height presented in Figure 4 shows that the higher the pressure, the lower the microalgal concentration in the DAF contact tank. Lower microalgal concentration was preferable for the flotation column height since most of the microalgal particles readily floated to the surface. At $0 \mathrm{~min}$, the microalgal concentration at the bottom of the flotation column $(10 \mathrm{~cm})$ was the lowest and the highest 
at the top of the column $(40 \mathrm{~cm})$. Once the flotation time reached $30 \mathrm{~min}$, the microalgal concentration started to decrease as most microalgal floc particles started to float atop. The flotation was effective within 10 to $15 \mathrm{~min}$ at 2 and 2.2 bar, however, the microalgal concentration remained the same from 15 to $30 \mathrm{~min}$. At $30 \mathrm{~min}$ flotation time, the microalgal concentration reached almost 0.027 $\mathrm{g} / \mathrm{L}$ at all flotation column heights for 2.2 bar. When the saturator pressure was lowered to 2 bar, the value increased slightly to approximately $0.034 \mathrm{~g} / \mathrm{L}$ at all column heights. It was believed that the saturator pressure at 2.2 bar produced sufficiently suitable sized bubbles that could enhance the attachment and collision of the floc particles with the bubbles. Recent study evaluated the effect of operational parameters including saturator pressure using $6 \mathrm{~L}$ laboratory DAF setup in batch-wise for the separation of Saccharomyces cerevisiae from yeast fermentation broth (Gulden et al. 2020). From the study, the bubble size was measured and it was found that increasing saturator pressure did reduce the bubble Sauter mean diameter. Hence, the finding further proved the probability of collision between bubbles and particles at higher saturator pressure, similar to this study (Gulden et al. 2020).



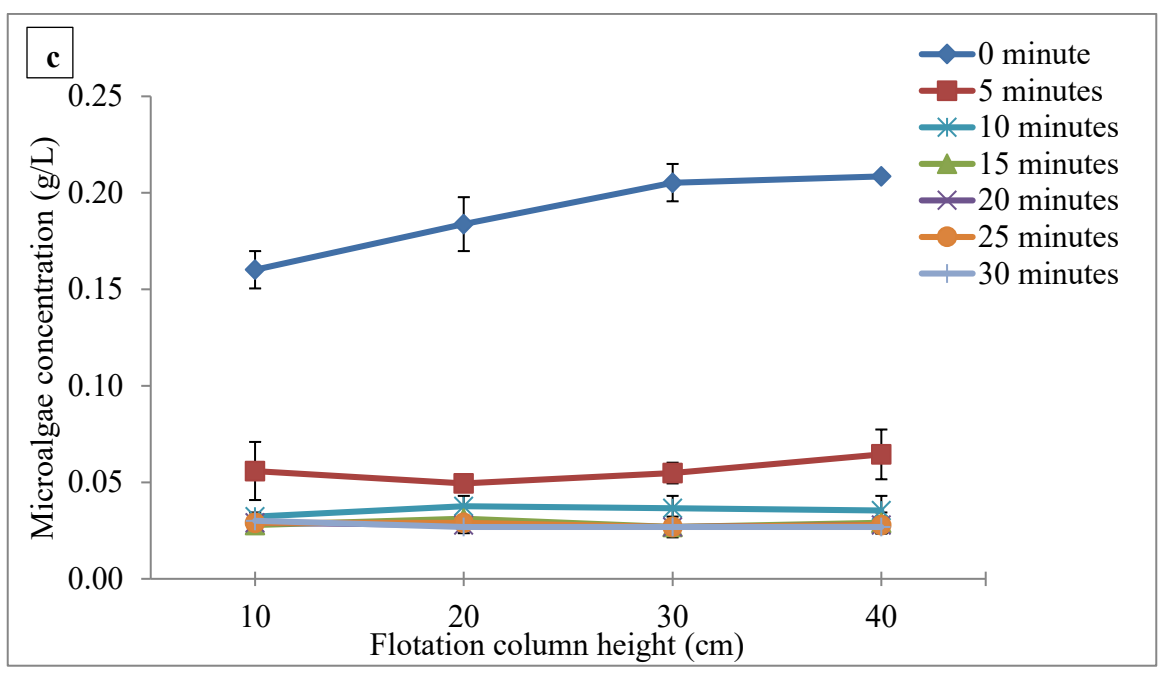

FIGURE 4. Microalgal concentration at different flotation column height (volume: $6 \mathrm{~L}$ ):

(a) 1.8, (b) 2.0, and (c) 2.2 bar

EFFECT OF DIFFERENT INITIAL MICROALGAL VOLUME

The concentration of microalgae within the culture is the most significant factor for maximum harvesting efficiency (Niaghi et al. 2015). The initial microalgal culture volumes attempted in this study was to imitate the effect of different initial culture volumes tested in a previous report (Zhang et al. 2014). Generating the ideal ratio of bubble concentration to the number of flocs is important. Therefore, different concentrations were assessed to evaluate the capability of the bubbles to capture the microalgal flocs. Figure 4(c), Figure 5(a), and Figure 5(b) show the concentration of microalgae with different volumes of initial microalgal culture of 6,8 , and $10 \mathrm{~L}$, respectively. From the results, it could be deduced that the higher the volume of microalgal culture used, the higher the microalgal concentration. The microalgal concentration was the highest at 30 and $40 \mathrm{~cm}$ of the flotation column height at $0 \mathrm{~min}$ for all the volumes tested. There was not much difference observed between the microalgal concentration at 30 and $40 \mathrm{~cm}$ of flotation height. At the point above $20 \mathrm{~cm}$ of flotation column height, the bubbles started to come into contact with microalgal particles and adhere to them. However, below the height of $20 \mathrm{~cm}$, probably much smaller bubbles were generated and as the bubbles rose towards the surface from the depth of flotation column, some bubbles grew in size as they moved to the separation column. However, the growth of the bubble size was reported to be small (Edzwald 2010). The varying sizes of bubbles within the flotation tank ranged between 40 and $80 \mu \mathrm{m}$, while 50 to $150 \mu \mathrm{m}$ within the separation zone with the typical pressure of 4 to 6 bar (400 to $600 \mathrm{kPa}$ ) within DAF (Edzwald 2010).
The microalgal concentration was the highest using $10 \mathrm{~L}$ culture even at $20 \mathrm{~cm}$ height at $0 \mathrm{~min}$ due to the high amounts of microalgal particles. However, the concentration reduced as the flotation time reached 30 $\min$. As for the $6 \mathrm{~L}$ of initial volume used, the microalgal concentration reduced to almost $0.027 \mathrm{~g} / \mathrm{L}$ under different flotation column heights at $30 \mathrm{~min}$. Increasing the initial volume to $8 \mathrm{~L}$ caused an increase to approximately $0.035 \mathrm{~g} / \mathrm{L}$. With $10 \mathrm{~L}$ of culture volume, the microalgal concentration increased rapidly between 0.050 and 0.056 $\mathrm{g} / \mathrm{L}$ from $10 \mathrm{~cm}$ to $40 \mathrm{~cm}$ of flotation column height. Flotation was observed to be a little slower as the culture volume was increased due to a higher number of floc particles compared to the limited number of bubbles generated (Zhang et al. 2014). This was because the increase in the number of flocs with increment in the initial algal dry weight required more air bubbles (Zhang et al. 2014). Therefore, it could be deduced that the bubbles generated in this study were insufficient to capture the floc particles when the concentration of initial algal culture increased due to an increase in the culture volume. In order to understand the floc-bubble interaction, Zhang et al. (2014) developed a DAF algal harvesting model through the employment of white water blanket model. According to the model, it was predicted that more bubbles were attached to larger flocs when the recycle ratio was increased and insufficient bubbles were noted for smaller flocs that deteriorated harvesting efficiency. A study conducted by Zhang et al. (2017) also evaluated the effects of cell density on the recovery rate of Chlorella sp. Harvesting was done using instant air dissolution method where microbubbles were generated using jet 
microbubble generator. A varying cell density of algae from 200 to $500 \mathrm{mg} / \mathrm{L}$ was used. The results obtained indicated that lower cell density increased the recovery rate due to a higher ratio of microbubbles to microalgae. However, higher recovery rate $(89.57 \%)$ was recorded using 300 $\mathrm{mg} / \mathrm{L}$ of microalgal cell density (Lin et al. 2011).
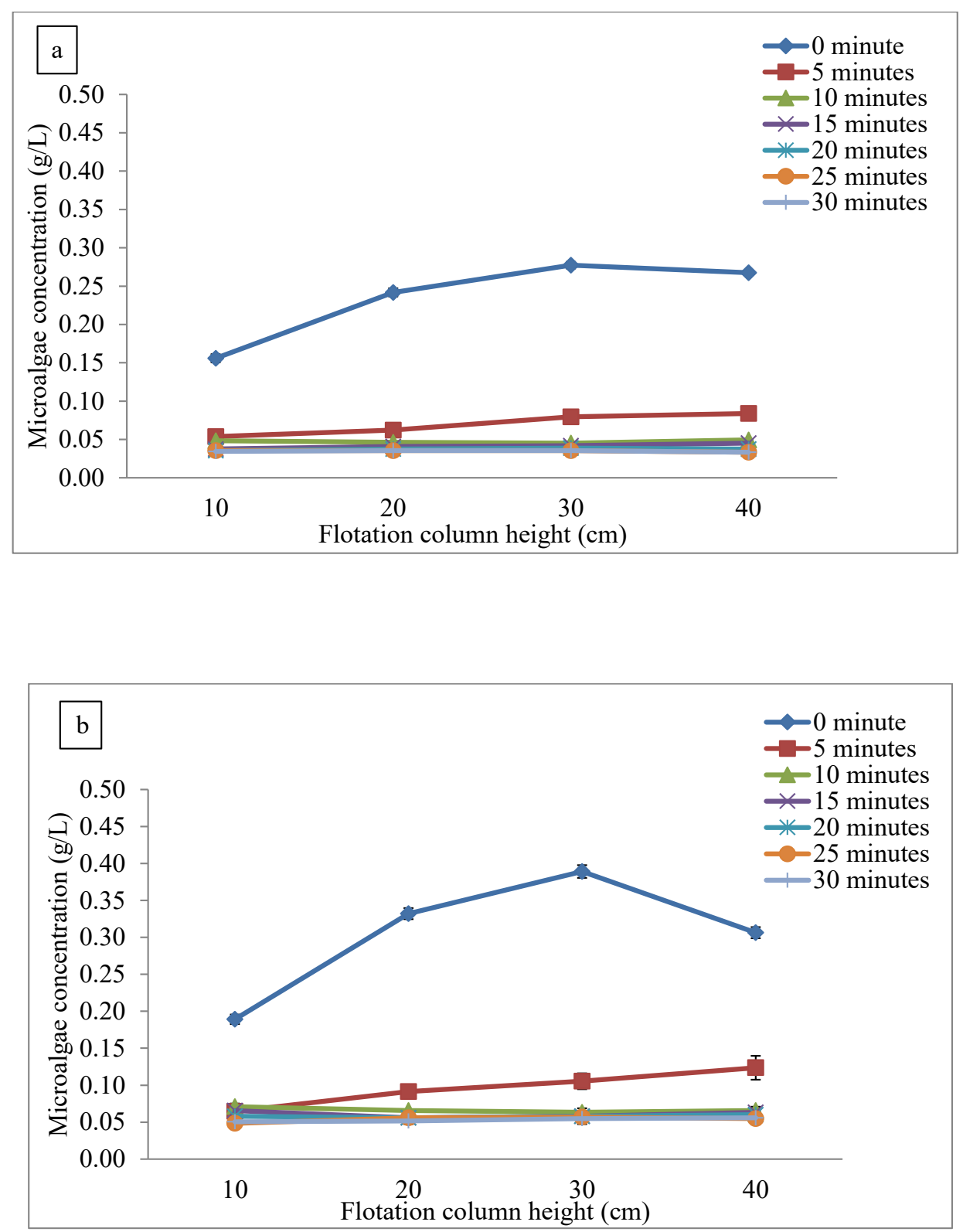

FIGURE 5. Algal concentration at different flotation column height (Pressure: 2.2 bar),

$$
\text { a) } 8 \mathrm{~L} \text {; b) } 10 \mathrm{~L}
$$

\section{TOTAL SOLID (\%) AND BIOMASS YIELD}

Effective harvesting could be achieved with concentrated microalgal slurry and maximum biomass recovery.
Hence, the total solid and biomass yield were analysed to further evaluate the efficiency of the DAF process. Figure 6(a) illustrates the DAF harvesting of microalgae. It was 
found that the increased concentration of total solid with the increased saturator pressure corresponded to a higher yield of the harvested microalgae biomass (Table 1).

However, the yield was less than the actual value due to the inferior design of the separation column where some microalgal flocs were trapped inside the top end of the separation column as shown in Figure 6(b). This problem was more apparent when $8 \mathrm{~L}$ and $10 \mathrm{~L}$ volumes were used. Hence, these resulted in lower yields for both 8 and $10 \mathrm{~L}$ volumes of microalgal culture (Table 2). The total solid concentrations were more than $3 \%$ for all the volumes tested. This strongly indicated that the application of DAF for harvesting Nannochloropsis sp. in this study was able to concentrate the microalgal biomass to the highest total solid $(3.48 \pm 0.54 \%)$ regardless of the microalgal concentration tested. In a separate study, bench-scale DAF technology was applied to concentrate algae from wastewater with prior coagulation using C-FLOC 60 cationic polymer (Wiley et al. 2009). DAF saturator pressure was fixed at $450 \mathrm{kPa}$ (4.5 bar) with varying ratio of wastewater to flotation water. Based on the study, microalgae harvest using DAF yielded a total solid concentration of more than $4 \%$ up to a maximum of $5 \%$ under different ratios of wastewater to flotation water. It was observed that DAF operating under a 2:1 ratio of wastewater to flotation water gave an ideal proportion for effective harvesting (Wiley et al. 2009). Additionally, higher saturator pressure was required in the previous study than for the current study to enhance the harvesting process. The weakness of DAF lies in its high power consumption due to the compression stage and the high pressure requirement to produce small bubbles (Wiley et al. 2009). The former was proven by Wiley et al. (2009) where they reported that DAF required high energy $\left(7.6 \mathrm{kWh} / \mathrm{m}^{3}\right)$ compared to the energy consumption of suspended air flotation. In another study, optimal saturator pressure at $3 \mathrm{~atm}$ (3.04 bar) appeared sufficient to achieve removal efficiency greater than $90 \%$ for algae concentration higher or equal to $500 \mathrm{mg} / \mathrm{L}$ (Niaghi et al. 2015). Data collected from the same study also reported that low power consumption $\left(0.0025 \mathrm{kWh} / \mathrm{m}^{3}\right)$ was achievable when no flocculant was added during the pilotscale DAF. Hence, it was able to reduce the operating cost (Niaghi et al. 2015). However, these studies (Niaghi et al. 2015; Wiley et al. 2009) focused on algal removal from water (considered wastewater) with lower concentration than the present study, as flocculant was utilised to increase the particle size of Nannochloropsis sp. In the current study, saturator pressure at 2.2 bar yielded better results probably due to the use of AFlok-BP1.

TABLE 1. Total solid and yield of harvested biomass at different saturator pressure

\begin{tabular}{|c|c|c|}
\hline Pressure (bar) & Total solid $(\%)$ & Yield ( $\mathrm{g}$ of harvested biomass/g of initial biomass concentration) \\
\hline 1.8 & $1.16 \pm 0.23$ & $0.55 \pm 0.02$ \\
\hline 2.0 & $2.26 \pm 0.09$ & $1.44 \pm 0.04$ \\
\hline 2.2 & $3.19 \pm 0.01$ & $1.70 \pm 0.05$ \\
\hline
\end{tabular}

TABLE 2. Total solid and yield of harvested biomass at different sample volumes

\begin{tabular}{|c|c|c|}
\hline Volume (L) & Total solid (\%) & Yield ( $\mathrm{g}$ of harvested biomass/g of initial biomass concentration) \\
\hline 6 & $3.19 \pm 0.01$ & $1.70 \pm 0.05$ \\
\hline 8 & $3.48 \pm 0.54$ & $1.59 \pm 0.13$ \\
\hline 10 & $3.24 \pm 0.11$ & $1.41 \pm 0.08$ \\
\hline
\end{tabular}




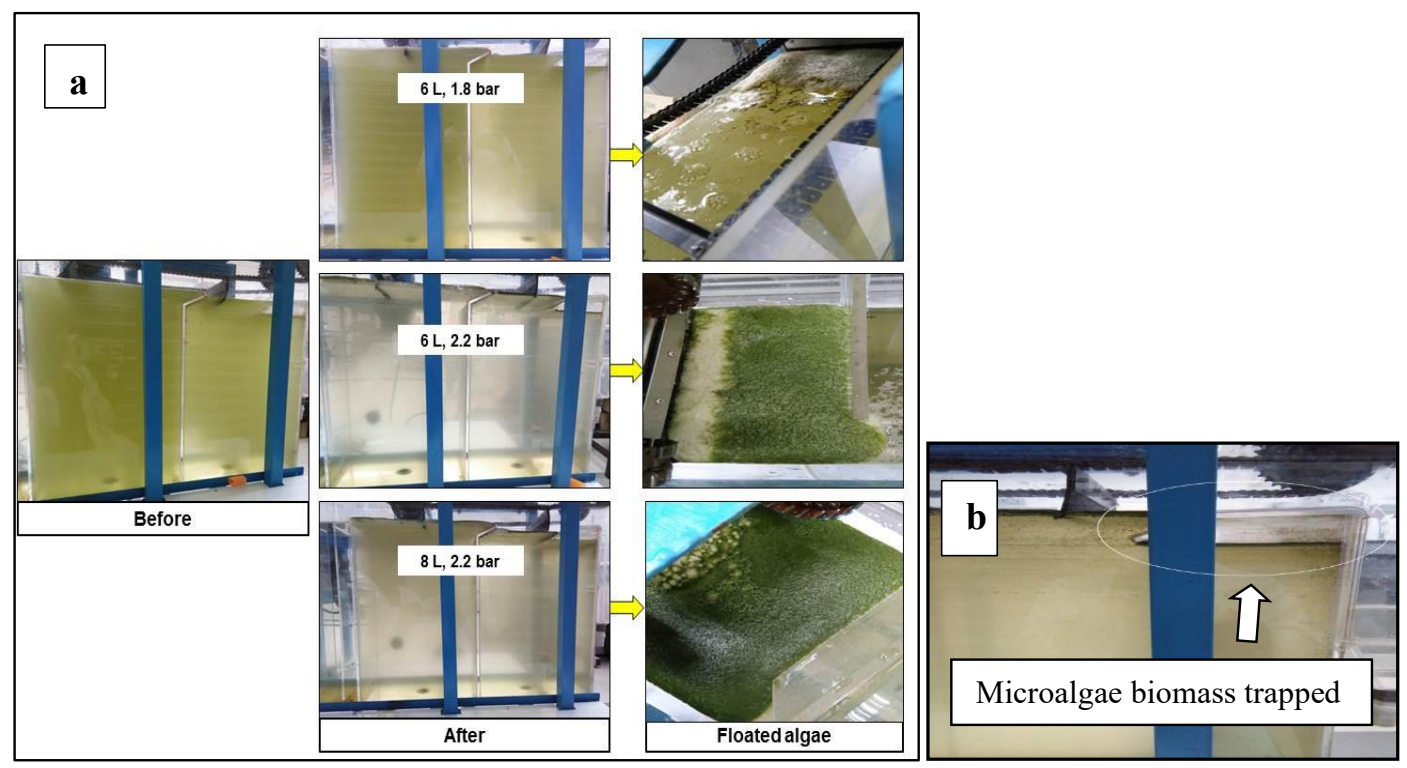

FIGURE 6. (a) DAF harvesting of microalgae, and (b) microalgal biomass trapped inside the separation column

The feasibility of the fabricated DAF unit in this study could add new knowledge to the harvest of lipidrich marine microalgae Nannochloropsis sp. through the utilisation of natural biopolymer AFlok-BP1. Additionally, flocculated Nannochloropsis sp. using AFlok-BP1 was observed to enhance lipid yield up to $18.6 \mathrm{mg} / \mathrm{g}$ at $180 \mathrm{mg} / \mathrm{L}$ compared to using aluminium sulphate $(17.7 \mathrm{mg} / \mathrm{g})$ or sodium hydroxide $(15.8 \mathrm{mg} / \mathrm{g})$ (Omar et al. 2017). However, further research may be carried out to improve the performance of DAF unit compared to the current study.

\section{CONCLUSION}

Based on the results, lipid-rich marine microalga Nannochloropsis sp. was successfully harvested using the DAF technique. Flocculation using natural biopolymer AFlok-BP1 was effective prior to the initiation of microalgal biomass to DAF. DAF harvesting was most efficient at the highest saturator pressure of 2.2 bar by yielding the highest total solid content of more than $3 \%$ with a higher yield of harvested biomass. When microalgal culture was added to a $6 \mathrm{~L}$ volume at 2.2 bar, microalgal concentration was the lowest within the flotation column. The findings provided feasible alternatives for future microalgal harvesting using DAF, especially for scalability purposes.

\section{ACKNOWLEDGEMENTS}

This research was supported by the UPM-IPB research grant (GP-IPB/2016/9483900) from Universiti Putra Malaysia (UPM). The authors acknowledged and were grateful for the support received.

\section{REFERENCES}

Barros, A.I., Goncalves, A.L., Simoes, M. \& Pires, J.C.M. 2015. Harvesting techniques applied to microalgae: A review. Renewable and Sustainable Energy Reviews 41: 14891500.

Besson, A. \& Guiraud, P. 2013. High-pH-induced flocculationflotation of the hypersaline microalga Dunaliella salina. Bioresource Technology 147: 464-470.

Dassey, A. \& Theegala, C. 2012. Optimizing the air dissolution parameters in an unpacked dissolved air flotation system. Water 4: 1-11.

Edzwald, J.K. 2010. Dissolved air flotation and me. Water Research 44: 2077-2106.

Fuad, N., Omar, R., Kamarudin, S., Harun, R., Idris, A. \& Wan Azlina, W.A.K.G. 2018. Effective use of tannin based natural biopolymer, AFlok-BP1 to harvest marine microalgae Nannochloropsis sp. Journal of Environmental Chemical Engineering 6: 4318-4328.

Gerardo, M.L., Van, D.H.S., Vervaeren, H., Coward, T. \& Skill, S.C. 2015. Harvesting of microalgae within a biorefinery approach: A review of the developments and case studies from pilot-plants. Algal Research 11: 248-262. 
Gulden, S.J., Riedele, C., Kopf, M.H. \& Nirschl, H. 2020. Potential of flotation as alternative separation process in biotechnology with focus on cost and energy efficiency. Chemical Engineering Science 218(8): 115117.

Han, M., Kim, T. \& Kim, J. 2007. Effects of floc and bubble size on the efficiency of the dissolved air flotation (DAF) process. Water Science and Technology 56: 109-115.

Harun, R., Singh, M., Forde, G.M. \& Danquah, M.K. 2010. Bioprocess engineering of microalgae to produce a variety of consumer product. Renewable and Sustainable Energy Reviews 14: 1037-1047.

Henderson, R.K., Parsons, S.A. \& Jefferson, B. 2008. Successful removal of algae through the control of zeta potential. Separation Science and Technology 43: 1653-1666.

Kim, T., Park, H. \& Han, M. 2017. Development of algae removal method based on positively charged bubbles. KSCE Journal of Civil Engineering 7(21): 2567-2572.

Kim, M.S. \& Kwak, D.H. 2020. Auto/bio-flocculation conditions to separate algal particles without chemical coagulants for flotation and sedimentation processes. Separation Science and Technology 55(6): 1185-1196.

Kwon, H., Lu, M., Lee, E.Y. \& Lee, J. 2014. Harvesting of microalgae using flocculation combined with dissolved air flotation. Biotechnology and Bioprocess Engineering 19: 143-149.

Laamanen, C.A., Ross, G.M. \& Scott, J.A. 2016. Flotation harvesting of microalgae. Renewable and Sustainable Energy Reviews 58: 75-86.

Leite, L.D.S., Santos, P.R.D. \& Daniel, L.A. 2019. Microalgae harvesting from wastewater by $\mathrm{pH}$ modulation and flotation: Assessing and optimizing operational parameters. Journal of Environmental Management 254: 109825.

Liu, J., Song, Y. \& Qiu, W. 2017. Oleaginous microalgae Nannochloropsis as a new model for biofuel production: Review \& analysis. Renewable and Sustainable Energy Reviews 72: 154-162.

Lin, Z., Kuang, Y.L. \& Leng, Y.W. 2011. Harvesting microalgae biomass by instant dissolved air flotation at batch scale. Advanced Materials Research 236-238: 146-150.

Ndikubwimana, T., Chang, J., Xiao, Z., Shao, W., Zeng, X., $\mathrm{Ng}$, I.S. \& Lu, Y. 2016. Flotation: A promising microalgae harvesting and dewatering technology for biofuels production. Biotechnology Journal 11: 315-326.
Niaghi, M., Mahdavi, M.A. \& Gheshlaghi, R. 2015. Optimization of dissolved air flotation technique in harvesting microalgae from treated wastewater without flocculants addition. Journal of Renewable and Sustainable Energy 7: 1-20.

Omar, R., Idris, A., Harun, R., Kamarudin, S., Wan Azlina, W.A.K.G., Kamal, S.M., Biak, D.R.A. \& Fuad, N. 2017. Comparison of lipid quality of Nannochloropsis sp. flocculated via autoflocculation, AFlok-BP1 and Alum. 5th International Symposium on Applied Engineering and Sciences (SAES2017), Universiti Putra Malaysia, Serdang, Selangor, $14^{\text {th }}-15^{\text {th }}$ November 2017.

Sharma, K.K., Garg, S., Li, Y., Malekizadeh, A. \& Schenk, P.M. 2013. Critical analysis of current microalgae dewatering techniques. Biofuels 4: 397-407.

Wiley, P.E., Brenneman, K.J. \& Jacobson, A.E. 2009. Improved algal harvesting using suspended air flotation. Water Environment Research 81: 702-708.

Zhang, X., Hewson, J.C., Amendola, P., Reynoso, M., Sommerfeld, M., Chen, Y. \& Hu, Q. 2014. Critical evaluation and modeling of algal harvesting using dissolved air flotation. Biotechnology and Bioengineering 111: 24772485.

Zhang, W.H., Zhang, J., Zhao, B. \& Zhu, P. 2015. Microbubble size distribution measurement in a DAF system. Industrial \& Engineering Chemistry Research 54: 5179-5183.

Zhang, X., Wang, L., Sommerfeld, M. \& Hu, Q. 2016. Harvesting microalgal biomass using magnesium coagulation-dissolved air flotation. Biomass and Bioenergy 93: 43-49.

Zhang, H., Lin, Z., Tan, D., Liu, C., Kuang, Y. \& Li, Z. 2017. A novel method to harvest Chlorella $\mathrm{sp}$. by co-flocculation/air flotation. Biotechnology Letters 39: 79-84.

Department of Chemical and Environmental Engineering Faculty of Engineering

Universiti Putra Malaysia

43400 UPM Serdang, Selangor Darul Ehsan

Malaysia

*Corresponding author; email: rozitaom@upm.edu.my

Received: 22 March 2020

Accepted: 20 Jun 2020 